\title{
QUALITY REVIEW OF AN ENVIRONMENTAL IMPACT STUDY ON THE DUPLICATION OF A STRETCH OF BR 153 HIGHWAY IN THE STATE OF SÃO PAULO - BRAZIL
}

\author{
REVISÃO DA QUALIDADE DE UM ESTUDO DE \\ IMPACTO AMBIENTAL NA DUPLICAÇÃO DE UM \\ TRECHO DA RODOVIA BR 153 NO ESTADO DE SÃO \\ PAULO - BRASIL
}

\section{Kaio Guilherme Cuoghi}

Faculdade de Economia, Administração e Contabilidade de Ribeirão Preto - FEARP, Universidade de São Paulo - USP, Av. Bandeirantes 3900, Ribeirão Preto 14040-900, Brasil - E-mail: kaiocuoghi@gmail.com

\begin{abstract}
The field of Environmental Impact Assessment (EIA) has been studied for decades and applied in several countries, including Brazil, since its regimentation in 1986. In this research, EIA study approach focused on the analysis of procedural issues concerning, specifically, the quality of the Environmental Impact Study (EIS). The general objective of this inquiry was to assess the quality of the EIS on the duplication of Transbrasiliana Highway, BR 153, on the stretch of the city of São José do Rio Preto, state of São Paulo - Brazil, identifying its gaps and best practices by means of the application of the European Community checklist created to review environmental impact studies, the Guidance on EIA - EIS Review. This study is qualitative in nature and had its data collected by means of public documents obtained from DNIT (National Traffic Department) and of information available in several websites. The process of data generation occurred through a questionnaire sent to a regional environmental expert. The analysis of the data showed that the referred EIS had gaps especially in areas such as description of the project, mitigation and alternatives - fields whose marks coincide with the ones found in studies done using the same guidelines in countries such as Spain, Portugal and Estonia. Besides, it was possible to identify new information about the project and about environmental impacts through the questionnaire sent to the environmental expert.
\end{abstract}

Keywords: Environmental Impact Assessment. Environmental Impact Study. Checklist. Transbrasiliana Highway - BR 153.

\section{RESUMO}

A Avaliação de Impacto Ambiental (AIA) é alvo de estudo há décadas, sendo aplicada em uma centena de países, inclusive no Brasil, desde sua regulamentação em 1986. A abordagem de estudo da AIA, neste trabalho, centrou-se na análise da questão processual, mais especificamente, na qualidade do Estudo de Impacto Ambiental (EIA). O objetivo geral foi avaliar a qualidade do EIA, identificando as lacunas e boas práticas nele encontradas sobre a duplicação da Rodovia Transbrasiliana, BR 153, no trecho da cidade de São José do Rio Preto no estado de São Paulo Brasil, por meio da aplicação da lista de verificação elaborada pela Comissão Europeia para revisão 
dos estudos de impacto ambiental, a Guidance on EIA - EIS Review. A pesquisa foi de natureza qualitativa, com coleta de dados em documento público solicitado ao DNIT (Departamento Nacional de Infraestrutura de Transportes), informações contidas em portais eletrônicos gerais e, também, por meio de um questionário enviado a um especialista ambiental da região. A análise dos dados permitiu identificar que o EIA em questão apresentou lacunas em áreas como descrição do projeto, mitigação e alternativas - áreas estas cujas notas coincidem com as encontradas em estudos feitos com o mesmo guia em países como Espanha, Portugal e Estônia. Além disso, foi possível identificar informações não presentes no EIA sobre o projeto e sobre os impactos ambientais pelo envio do questionário a um especialista ambiental.

Palavras-chave: Avaliação de Impacto Ambiental. Estudo de Impacto Ambiental. Lista de verificação. Rodovia Transbrasiliana - BR 153.

\section{INTRODUCTION}

Environmental Impact Assessment (EIA) is defined as "the process of identifying, predicting, evaluating and mitigating the biophysical, social, and other relevant effects of development proposals prior to major decisions being taken and commitments made" (IAIA, 1999). Studies on EIA emerged from discussions in the 70's, being the United States of America the first country to regiment it by means of NEPA (National Environmental Policy Act) in 1969. The impact assessment, established by directive 85/337 from the European Economic Community, was approved by members of the European Commission in 1985 and is currently used in over 100 countries, including developed and developing nations. However, it is important to mention that some studies show that EIA has weak influence on enterprise operational decisions (JAYA et al., 2007).

Brazilian legislation for EIA started to be recognized especially over the past decades. In 1981, the Environmental National Policy was set by Decree-Law 6938/1981, whose Article 9 Incise IV establishes "the licensing and the review of effective or potentially polluting" (BRASIL, 1981) as one of its tools. Afterwards, the EIA was regimented by CONAMA (National Environment Council) Resolution 1/1986, which included the need to develop a study and a report for specific enterprises, respectively the Environmental Impact Statement (EIS) and the Environmental Impact Report (EIR). In 1997, CONAMA Resolution 237/1997 settled the rules for environmental licensing and its subordinate activities.

Besides historical issues, it is important to enhance the existence of two EIA study approaches: an approach focused on the process - used when all its assumptions and best practices are presented - and an approach focused on the analysis of the influence of the study on decision making and on the generation of practical effects (SADLER, 1996; MACINTOSH, 2010 apud ALMEIDA et al., 2012). Some studies in Brazil and abroad also deal with the decrease of environmental impacts by enterprises through new techniques and approaches (FERNANDES, 2000; GALHARTE; CRESTANA, 2010; WUA et al., 2014).

Aiming at analyzing the quality of the EIS, identifying its gaps, several authors applied techniques developed on their own - checklists, and definition of criteria and sub criteria -, by national regulatory environmental entities - such as the European Community checklist created in 2001 - or, yet, experts' reports (MONTAÑO et al., 2014; CANELASA et al., 2005; APPIAHOPOKU, 2001; ALMEIDA et al., 2012). Checklists have their advantages recognized because of the easiness of context adaptation (ALMEIDA et al., 2012), the sharing of important questions and the potential for quality analysis of the project (KAJA, 2010). However, when searching for studies using checklists in Brazil on databases such as Scielo and Scopus it could be noticed that the checklists were applied neither on projects of duplication of highways nor in situations when 
environmental impacts could be considered less aggressive due to the localization of endeavors in urbanized areas.

That way, this research focused on the procedural approach of the EIA study and aimed at assessing the quality of the EIA by means of the identification of gaps and best practices on the EIS of the duplication of Transbrasiliana Highway, BR 153, on the stretch of São José do Rio Preto-SP Brazil from $54.3 \mathrm{~km}$ to $72.1 \mathrm{~km}$. For this purpose, the European Community checklist, Guidance on EIA - EIS Review was applied to review studies on environmental impacts. A comparison between the results of the application of the list on the referred EIA and the results found on European countries was also done, as well as the application of a questionnaire to a regional environmental expert. The characteristics which justify the option for BR 153 , specifically from $54.3 \mathrm{~km}$ to $72.1 \mathrm{~km}$, as object of this study were, besides the importance of the highway in terms of extension and of its role as goods outlet, the increase in the number of accidents which occurred on the referred stretch and the presence of the project in an urbanized area.

\section{MATERIALS AND METHODS}

This research is qualitative in nature because it deals with concepts of the understanding (COOPER; SCHINDLER, 2014). The data collected consisted of a public document (EIS) obtained from DNIT (National Traffic Department) and of information found at ANTT's (Land Transportation National Agency) website, as well as other portals related to the highway concessionaire and to Brazil's Ministry of Planning. Also, data was generated through a questionnaire applied to a regional environmental expert.

The first stage of the study aimed at analyzing the state of the art of themes related to EIA and the quality of the EIS reported on articles indexed at Web of Science and Scielo data bases.

After identifying the mechanisms applied in the analysis of the EIS of the project and noticing that, in Brazil, there is not an official governmental mechanism to review the EIS using checklists as there is in Europe, we chose to apply the European Community checklist Guidance on EIA - EIS Review on the EIS about the stretch of BR 153 to be duplicated in the city of São José do Rio Preto in state of São Paulo - Brazil, which was provided by DNIT (PREFEITURA MUNICIPAL DE SÃO JOSÉ DO RIO PRETO, 2009). The use of the referred list occurred due to its wide use in international articles (KAJA, 2010; CANELASA et al., 2005) and to the possibility of comparing the case studied in this research with the scenario of the EIS in other countries, a comparison which would be hard to make if we opted to use Brazilian checklists.

After the application of the European checklist, there was an analysis of the responses given by the environmental expert on the area of São José do Rio Preto-SP, who holds two decades of professional experience in the field, to a non-structured five-question questionnaire - created in and for this study - with the aim of identifying the peculiarities of the environmental impacts of the project. The questions were: (i) What are the most relevant environmental, social and economic impacts involved in the construction of the project? Which of them should be prioritized for mitigation? (ii) Are there alternatives to the elaboration of the project? If so, are they feasible? Are the impacts of this project the lowest? (iii) Is the project proper for the structure of the city? (iv) Are there any perspectives that the construction will improve traffic in the city? (v) Is there any other information you believe is relevant to be explicit as environmental, social and/or economic impact?

\subsection{Environmental impact study quality analysis method}

European Community Guidance on EIA - EIS Review checklist created in 2001 - based on Directive 337 from 1985 and amended by Directive 11 from 1997 (EUROPEAN UNION, 1997) aims at helping governments to improve the quality of their EIS, besides being a mechanism 
capable of generating studies and comparisons. The method introduced by the referred guide is divided into seven sections - Description of the project, Consideration of alternatives, Description of environment likely to be affected by the project, Description of the likely significant effects of the project, Description of mitigation, Nontechnical summary, Quality of presentation - and there are two ways to use it, one which is useful for the analysis of the quality of the study, and one for comparisons with other cases (ENVIRONMENTAL RESOURCES MANAGEMENT, 2001).

Concerning the quality analysis of the study, the first step to use the method is to observe, in all sections, whether the items are relevant for the comprehension of the study, marking 'yes' or 'no' on the respective determined spaces. If important items for the analysis are missing, it is recommended to complete the checklist with the required items. The second step is to analyze whether information on the study are sufficient for decision making, in case the items are considered important for the study. If the information is not enough, it is necessary to mark 'no' and identify the omitted information, marking them in another space (ENVIRONMENTAL RESOURCES MANAGEMENT, 2001).

For comparative studies, the guide suggests to use a grading system by means of which all the items from all the sections will be analyzed to reach a classification for each section. This way, the value of each section is aggregated and it is possible to find the value if the EIS as a whole (ENVIRONMENTAL RESOURCES MANAGEMENT, 2001). However, a formal methodological criterion is not well defined for the final grades of a section if the values presented by the items are incompatible. For the appraisal of the levels, reviewers can use the grades outlined in Chart 1:

Chart 1 - Grading items for Guidance on EIA - EIS Review checklist

A: Full provision of information with no gaps or weaknesses;
B: Good provision of information with only very minor weaknesses which are not of importance to
the decision;
C: Adequate provision of information with any gaps or weaknesses in information not being vital to
the decision process;
D: Weak provision of information with gaps and weaknesses which will hinder the decision
process but require only minor work to complete;
E: Very poor provision of information with major gaps or weaknesses which would prevent the
decision process proceeding and require major work to complete.

Source: Environmental Resources Management (2001)

\subsection{Environmental impact statement (eis) checklists}

EIS quality appraisal, as well as the identification of its gaps, can occur through the application of techniques created by researchers, by national environmental regimentation agencies or through reports developed by experts (APPIAH-OPOKU, 2001; CANELASA et al., 2005; ALMEIDA et al., 2012; MONTAÑO, 2014).

Among the techniques developed by researchers are the checklists and the delineation of assessment criteria and sub criteria. The advantages of checklists are the easiness of context adaptation (ALMEIDA et al., 2012), the possibility of sharing important questions and of analyzing the quality of the projects (KAJA, 2010). Almeida et al. (2012) applied two environmental impact quality study checklists - developed by Glasson, Therivel and Chadwick (2005) and by Sánchez (2006) - and an experts' appreciation to assess the implementation of a waste dump in Caraguatatuba-SP. The study demonstrated that the several tools used reached the same final classification in terms of faults and best practices. The study also showed that the checklists were useful tools for analysts and developers concerning the improvement of the quality of the EIS, therefore being a proper tool to assess the EIA in the state of São Paulo. Concerning criteria and sub criteria development, Montaño et al. (2014) investigated the quality of environmental impact study in three central hydroelectric facilities, making it possible to compare the EIS and demonstrating 
their technical weakness.

The Guidance on EIA - EIS Review is an example of the technique organized by environmental regimentation entities. A European study analyzed 46 projects which developed an environmental impact study in Portugal and Spain between 1998 and 2003 and four projects on highways and roads through the guide (CANELASA et al., 2005). The researchers observed that, 18 years after the establishment of the European directive (337/85), there was a significant percentage (22\% in Portugal and 30\% in Spain) of items graded level D on the checklist - grade which consists in weak provision of information with gaps and weaknesses in the study. Only $9 \%$ of the items in Spain and $0 \%$ in Portugal were graded A - which means full provision of information with no gaps or weaknesses (CANELASSA et al., 2005). The same guide in Estonia also did the appraisal of the quality of the EIS, using random sample of studies between 2001 and 2005 (KAJA, 2010). The study pointed the existence of great weaknesses in the area of description of the project, where over $66 \%$ of the items were graded D or E. The comparison of these data with studies in Portugal and Spain demonstrated that both were weak concerning projects, with $30 \%$ and $48 \%$ of the items graded D or E, respectively (KAJA, 2010). Finally, the study highlighted that mitigation initiatives and alternatives of consideration were sectors with high weaknesses in Estonia, Spain and Portugal (KAJA, 2010).

\section{RESULTS AND DISCUSSION}

\subsection{BR 153 on the stretch of São José do Rio Preto-SP}

The object of study of this research is a stretch of BR 153 Highway - best known as Transbrasiliana Highway in the state of São Paulo. It is the longest longitudinal highways in Brazil, with an extent of 3,566.3 km. Longitudinal highways longer than BR 153 are BR $116(4,566.5 \mathrm{~km})$, BR $101(4,551.4 \mathrm{~km})$, BR $163(4,426.7 \mathrm{~km})$ and BR $158(3,955 \mathrm{~km})$. BR 153, however, differs from those highways because it is located in the center of Brazil, overreaching eight states (DNIT, 2015). BR 153 stretch in São Paulo, which starts in the city of Icém-SP and ends in Ourinhos-SP, is about $347.7 \mathrm{~km}$ of extension. It is administered under concession arrangement by Transbrasiliana Concessionária de Rodovia S.A (Transbrasiliana Highway Concessionnaire PLC) enterprise, whose owner is Triunfo Investimento e Participações S.A (Triunfo Investments and Shareholdings PLC), being regimented and supervised by ANTT (TRANSBRASILIANA CONCESSIONÁRIA DE RODOVIA S.A., 2015).

The stretch of BR 153 in the state of São Paulo whose EIS was analyzed in this study comprehends the portion to be duplicated and the urban crossings to be built between $54.3 \mathrm{~km}$ and $72.1 \mathrm{~km}$ - which belong exclusively to the urban area of São José do Rio Preto-SP -, being surpassed by SP 310 and SP 425. According to the EIS (PREFEITURA MUNICIPAL DE SÃO JOSÉ DO RIO PRETO, 2009), the estimate cost of the project is R $\$ 180,000,000.00$ and it will be supported by DNIT with funds from Programa de Aceleração do Crescimento - Growth Acceleration Program (MINISTÉRIO DO PLANEJAMENTO, 2014).

Figure 1 shows the city of São José do Rio Preto-SP and emphasizes the highway. The traces in red and in blue are representatives of the areas to be duplicated and the traces in pink are representatives of stretches already duplicated. 


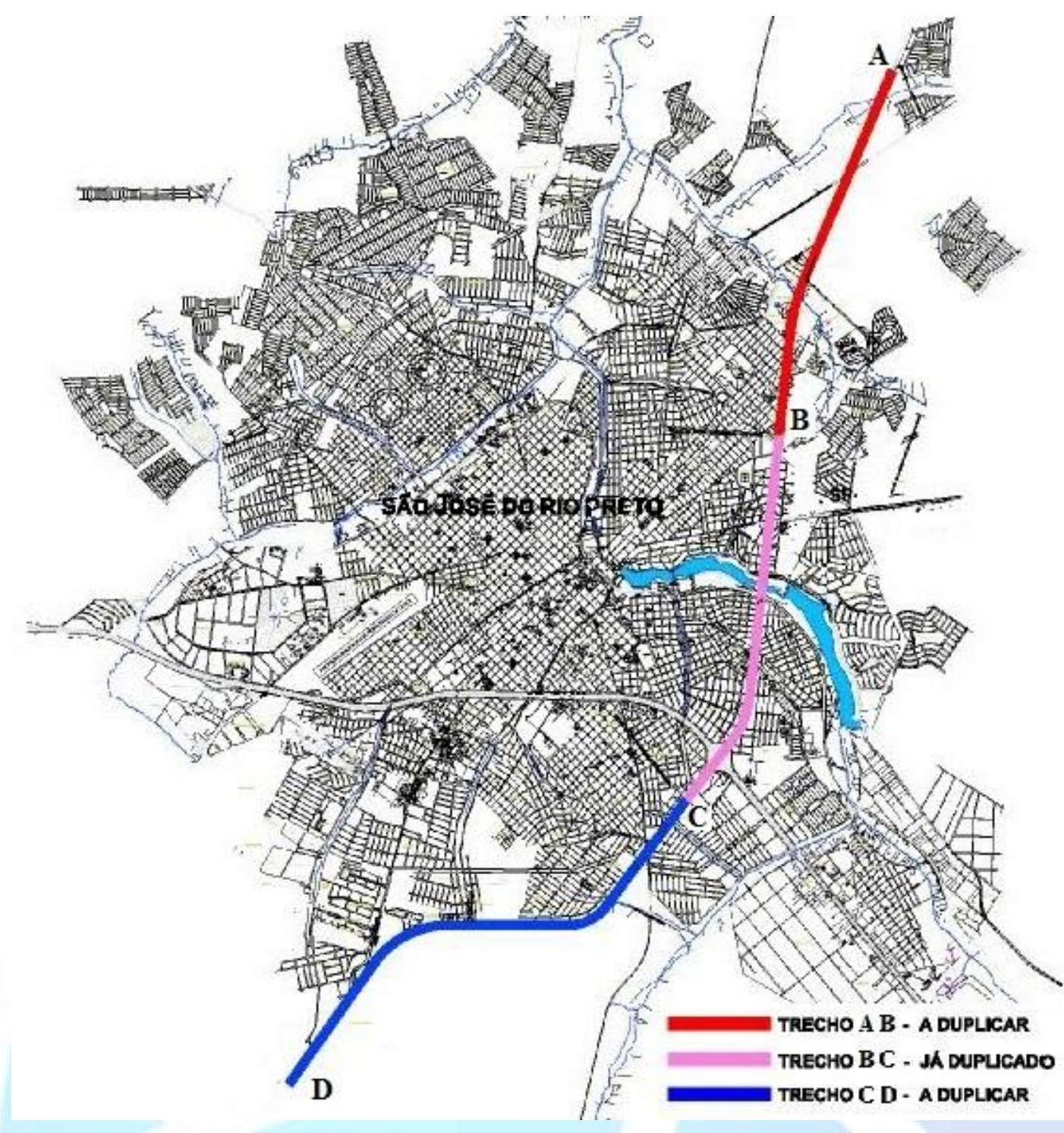

Figure 1. Map of the areas to be built through the EIS. Source: Modified from Prefeitura Municipal de São José do Rio Preto-SP (2009)

On the stretch of São Paulo $(0 \mathrm{~km}$ to $347.7 \mathrm{~km})$, the total average of accidents, considering the period of time ranging from 2008 to 2012, was of 1,043.2 total accidents; being 38.8 fatal accidents, 414.6 injury accidents and 589.9 non-injury accidents (ANTT 2008, 2009, 2010, 2011, 2012). Considering the stretch from $56 \mathrm{~km}$ to $76 \mathrm{~km}^{1}$, which corresponds to only $5.75 \%$ of the total extension of the highway in São Paulo $(347.7 \mathrm{~km})$, one can notice the high concentration of accidents on the stretch of São José do Rio Preto-SP. According to ANTT, $34.30 \%$ of total accidents on BR 153 in the state of São Paulo $(347.7 \mathrm{~km})$ occurred on the stretch of São José do Rio Preto $(20 \mathrm{~km})$, being $20.62 \%$ fatal accidents, $33.53 \%$ injury accidents and $35.71 \%$ non-injury accidents.

\subsection{Guidance on EIA - EIS Review application and international comparison}

The application of the Environmental Impact Declaration Global Appreciation as suggested

1 The EIS of the duplication of BR 153 on the stretch of São José do Rio Preto-SP points $54.3 \mathrm{~km}$ to $72.1 \mathrm{~km}$, however, the data of accidents closer to this stretch found at ANTT website ranged from $56 \mathrm{~km}$ to $76 \mathrm{~km}$. 
by the Guidance on EIA - EIS Review (2001) - as shown in chart 1 - exhibits the predominance of grades E (52.52\%) in all of the items from all sections of the guide, except the Nontechnical Summary and the Quality of the Presentation sections. Adding up grades E and D, the percentage rises for $64.03 \%$ in comparison to the other grades. This way, the EIS of the chosen stretch of BR $153(54.3 \mathrm{~km}$ to $72.1 \mathrm{~km})$, in general, can be classified in grade $\mathrm{E}$ and resembles the reality of 46 projects implemented between 1998 and 2003 in Portugal and Spain. It was analyzed by Canelasa et al. (2005), which had grade D in $22 \%$ of the projects in Portugal and $30 \%$ in Spain. However, opposing to Brazil, European Union has a guide which uses checklists since 2001, as well as an environmental directive (337/85) dated 1985.

Table 1 - Environmental Impact declaration Global Appreciation with grades of the sections

\begin{tabular}{|c|c|c|c|c|c|c|c|}
\hline Section & $\mathbf{A}$ & B & $\mathbf{C}$ & $\mathbf{D}$ & $\mathbf{E}$ & $\begin{array}{c}\text { Not } \\
\text { relevant }\end{array}$ & $\begin{array}{c}\text { Lack of } \\
\text { information }\end{array}$ \\
\hline Description of the Project & 0 & 1 & 5 & 0 & 30 & 3 & 9 \\
\hline $\begin{array}{l}\text { Consideration of } \\
\text { alternatives }\end{array}$ & 0 & 0 & 0 & 0 & 4 & 0 & 1 \\
\hline Local of the Project & 2 & 1 & 1 & 2 & 10 & 3 & 2 \\
\hline $\begin{array}{l}\text { Effects of the project/ } \\
\text { Characteristics of potential } \\
\text { impacts }\end{array}$ & 1 & 0 & 0 & 12 & 21 & 4 & 0 \\
\hline Mitigation & 0 & 1 & 1 & 0 & 8 & 0 & 0 \\
\hline Non technical summary & 0 & 0 & 0 & 0 & 0 & 0 & 7 \\
\hline Quality of presentation & 4 & 0 & 5 & 2 & 0 & 0 & 0 \\
\hline Total & 7 & 2 & 12 & 16 & 73 & 10 & 19 \\
\hline$\%$ & $5.04 \%$ & $1.44 \%$ & $8.63 \%$ & $11.51 \%$ & $52.52 \%$ & $7.19 \%$ & $13.67 \%$ \\
\hline
\end{tabular}

Source: Based on Guidance on EIA - EIS Review with amendments by the author.

Several specific sections showed common characteristics with portions of the European scenario. The Description of the Project section had a high percentage of grades E in its items $(83.33 \%)$. This information corroborates the study of projects done between 2001 and 2005 in Estonia, where it was possible to observe high weaknesses in the area of description of the project where more than $66 \%$ of the analyzed projects were graded D or E in this section (KAJA, 2010). When comparing this situation with the study conducted by Canelasa et al. (2005) in Portugal and Spain, it observes a high percentage of projects with weaknesses in this specific subdivision. The section of alternatives had four grades E, whereas the section of mitigation had eight grades E, one grade $\mathrm{B}$ and one $\mathrm{C}$, which demonstrates the weakness of this section. Likewise, the study developed by Kaja (2010) also shows that these two areas had weaknesses in Estonia, Portugal and Spain.

The items considered non-relevant for the analysis of the project were $10(7.19 \%)$ and 19 items (13.67\%) comprise the list about which was not possible to find information on the EIS of the project. Information to which this study did not have access, once they were part of attachments and programs, which that would be provided only after the granting of the operating license. However, although this later value consists in an indicator of limitation of the study, it is worthy to note that it does not alter the final grade classification due to the high number of items classified with grades $\mathrm{E}$ (73) when compared to the numbers presented by the rest.

Finally, it shall be highlighted that the items analyzed with level A were only seven $-5.04 \%$ in relation to the total -, four of them integrating the item quality of the presentation. This low quantity also corresponds to the percentage of items with level A - full provision of information with no gaps or weakness - found in Spain and Portugal, which had values lower than $10 \%$ in grade A in more than half of the items of the sample studies researched (CANELASA et al., 2005). This way, one can notice, once more, that, in general, the EIS of BR 153 on the stretch investigated in this paper had similar characteristics to the European reality. The best practices and gaps found on 
the EIS through the application of the European checklist are presented in Chart 2.

Chart 2 - Best practices and gaps found by the application of the checklist. Source: Author.

\begin{tabular}{|c|c|}
\hline Best practices & Gaps \\
\hline \multicolumn{2}{|l|}{ Description of the Project } \\
\hline \multirow[t]{5}{*}{$\begin{array}{l}\text { Presence of justification summary, objectives, needs, } \\
\text { description of the activities and several programs }\end{array}$} & Project not properly justified \\
\hline & Steps of the project not properly described \\
\hline & Lack of details on regional population and enterprises \\
\hline & $\begin{array}{l}\text { Lack of details on project production process, characteristics, } \\
\text { risks and accident risks }\end{array}$ \\
\hline & $\begin{array}{l}\text { Presence of several programs referring to the project, but not } \\
\text { detailed on the EIS document }\end{array}$ \\
\hline \multicolumn{2}{|l|}{ Consideration of alternatives } \\
\hline & $\begin{array}{l}\text { Lack of genuine and feasible alternatives to the project nor of } \\
\text { comparison of their effects }\end{array}$ \\
\hline \multicolumn{2}{|l|}{ Local of the Project } \\
\hline \multirow[t]{8}{*}{ Proper description of land topography and geology } & Poorly structured project scope \\
\hline & Lack of better studies on regional climate conditions \\
\hline & Lack of better hydrological studies \\
\hline & Lack of consideration of radiation and sound impact \\
\hline & $\begin{array}{l}\text { Poor description of flora and fauna, specially concerning } \\
\text { rivers }\end{array}$ \\
\hline & $\begin{array}{l}\text { Improper identification of the people that use the lands } \\
\text { around the area of the project, mentioning only the area of } \\
\text { indirect influence }\end{array}$ \\
\hline & Lack of discussion of data uncertainty \\
\hline & Lack of references \\
\hline \multicolumn{2}{|l|}{ Characteristics of environmental impacts } \\
\hline \multirow[t]{4}{*}{ Specification of arboreal species to be deforested } & $\begin{array}{l}\text { Lack of precise definition on how the traffic will flow when } \\
\text { the construction starts and after its end }\end{array}$ \\
\hline & Lack of specification of the generated waste product \\
\hline & $\begin{array}{l}\text { Lack of studies on the impacts to be caused by soil movement } \\
\text { and by the increase in the flow of vehicles after the } \\
\text { construction }\end{array}$ \\
\hline & $\begin{array}{l}\text { Lack of information on potential impacts to be caused on } \\
\text { local hydrology, air quality and demographic aspects }\end{array}$ \\
\hline \multicolumn{2}{|l|}{ Description of mitigation } \\
\hline $\begin{array}{l}\text { Presence of framework showing the mitigation of } \\
\text { effects }\end{array}$ & Lack of mitigation actions towards several impacts \\
\hline & Lack of justification for mitigation actions choices \\
\hline Mentioning to several programs & $\begin{array}{l}\text { Lack of consideration of potential mitigation actions negative } \\
\text { effects }\end{array}$ \\
\hline \multicolumn{2}{|l|}{ Quality of the presentation } \\
\hline \multirow[t]{4}{*}{$\begin{array}{l}\text { Proper document organization, with table of contents } \\
\text { and structuring of different areas }\end{array}$} & $\begin{array}{l}\text { Lack of cross-references, which hinders the possibility of } \\
\text { reading the document without stopping to consult information } \\
\text { available only in programs and attachments }\end{array}$ \\
\hline & Presence of high importance items in attachments only \\
\hline & Lack of some references \\
\hline & Lack of standardized layout guidelines \\
\hline
\end{tabular}




\subsection{Application of a questionnaire to a regional environmental expert}

When using checklists previously created by an author or, like this study, by European Commission, it is important to notice that many questions cannot be completely answered by the lists. Therefore, on the sections of Guidance on EIA - EIS Review (2001) lists, there are blank spaces to include necessary questions not present on the guide. That way, this section is dedicated to understand the reality of environmental, economic and social impacts according to the opinion of an environmental expert on the area of São José do Rio Preto-SP through the answers given to a questionnaire - this technique is similar to the expert report one, which is also used as an EIS assessment mechanism. The data collected allowed the identification of new gaps on the EIS of the project in relation to environmental impacts and corroborated some gaps already noticed when the checklist was used.

The data collected by the application of the questionnaire demonstrated that the main environmental impact that could occur on the project would be the risk of accidents involving trucks that transport hazardous products, once the highway, in the referred stretch, interconnects the petrochemical poles of Camaçari, in Bahia and Triunfo, in Rio Grande do Sul. This way, spills caused by trucks involved in accidents could happen and reach Rio Preto and Córrego da Felicidade, achieving, by extension, the municipal dam that supplies the city. Besides, a railway through which great quantities of fuel are transported also surpasses the highway. When the guide was applied in this study, it was informed that accidents that could happen on the highway were not considered and that the rivers had not been sufficiently studied; however, through the questionnaire, specific environmental impacts could be delineated and explained. The benefits of the inserting of specialists could also be found on the analysis of other EIS with applications in Brazil (MONTAÑO et al., 2014).

Regarding economic and social impacts, it was considered the valorization of lands around the highway, which can be occupied by housing purposes and others, focusing on the needs for proper municipal legislation that foresee such urban modifications. These data could be framed on the application of the guide when one observes that the area, in economic and social terms, was not well studied - only the direct influence area was briefly described on the EIS. This way, once more, an important specific impact was delineated and explained through the questionnaire.

Concerning the alternatives, the questionnaire revealed that the project did not consider them, but that, also according to the questionnaire, it shall have mechanisms to avoid accidents, diminish the emission of noises and suppress chemical products spill. These data meet the idea presented along the EIS, which is in favor of the construction of the endeavor, not eliciting any alternative, but listing some mechanisms to mitigate environmental damages. However, the checklist presented low grades on the item of alternatives of the project and showed the weakness of the lack of those alternatives.

When it comes to the project, the data showed that the approved one was considered as possibly not proper to the area, because there was the installation of new relevant-sized projects in the spot, such as a new shopping center and new allotments. Besides, in the opinion of the expert, side accesses to the highway should be resized due to the new projects and to the flow of vehicles coming from other highways. This way, there was the specification of a new consideration concerning the project.

Concerning the approval of the construction of the project, in a first moment, it was demonstrated that the duplication would be useful for traffic, but that, in the long term, there would be a saturation of the flow of vehicles due to a greater use of the routes. This data also complemented the one identified on the application of the guide.

Least, we present a synthesis of the impacts highlighted and of the considerations on the duplication of the highway and on urban crossings that could be identified in the responses given to the questionnaire by the regional expert. The synthesis was compared to the EIS as well as to the 
application of the checklist and is summarized in Chart 3 below. It was noticed that the information collected through the questionnaire was important to understand the peculiarities of the EIS on the duplication of BR 153 in the area of São José do Rio Preto-SP and that the information also complemented the environmental impacts and considerations about the project that the checklist presented (Chart 3).

Chart 3 - Impacts found through the application of the questionnaire. Source: Author.

\begin{tabular}{|l|l|l|}
\hline $\begin{array}{l}\text { Impacts highlighted/Considerations about } \\
\text { the project }\end{array}$ & $\begin{array}{l}\text { Were the impacts discussed when } \\
\text { the checklist was applied? }\end{array}$ & $\begin{array}{l}\text { Were the impacts present } \\
\text { on the EIS? }\end{array}$ \\
\hline $\begin{array}{l}\text { Containment of accidents with dangerous } \\
\text { products on the highway and on the railway } \\
\text { which surpasses it }\end{array}$ & $\begin{array}{l}\text { The topic was issued, but there was no } \\
\text { mention to this specific impact }\end{array}$ & No \\
\hline Marginal land plots appreciation & $\begin{array}{l}\text { The topic was issued, but there was no } \\
\text { mention to this specific impact }\end{array}$ & $\begin{array}{l}\text { The topic was issued, but } \\
\text { there was no mention to } \\
\text { this specific impact }\end{array}$ \\
\hline $\begin{array}{l}\text { Project should be better studied due to the } \\
\text { presence of new projects in the area }\end{array}$ & No & No \\
\hline $\begin{array}{l}\text { Need of better study on the loops that will } \\
\text { connect the investigated stretch of BR } 153 \text { to } \\
\text { new highways }\end{array}$ & No & \\
\hline
\end{tabular}

\subsection{Closing remarks}

Considering the general objective proposed - assess the quality of the EIS of the duplication of Transbrasiliana Highway, BR 153, on the stretch of São José do Rio Preto in the state of São Paulo . It was observed that the application of the European Community Guidance on EIA - EIS Review checklist promoted the identification of gaps and good practices on the EIS of the project. It could be noticed that the EIS of BR 153 on the studied stretch had more gaps than good practices when the checklist was applied. However, these results do not differ, in terms of various sections of the list, from the ones found in European study samples of the EIS in Spain, Portugal and Estonia.

The use of the questionnaire sent to a regional environmental expert allowed the finding of environmental, social and economic impacts, which were not, discussed when the checklist was applied and which were not present on the EIS of the project, besides being able to confirm other items, which were not approached by the checklist.

It could be demonstrated, therefore, that the checklist used was useful to analyze the quality of the aforementioned EIS - what did not mean, however, that, an analysis by a regional environmental expert was not worthy of consideration and that it was not necessary to explicit impacts and specific characteristics of the project in the area.

This way, it could be noticed that although the project was placed in an urbanized area there were relevant environmental impacts that could be identified through an EIS with no gaps. This could have happened in the studied case especially on what concerns local hydrology, once the highway is located in an area with intense fuel transportation. Therefore, the use of standardized guides, as the one used in this study, become an important tool to EIS analysis and elaboration.

The study was also useful to foster new studies on the quality of EIAs and, more specifically, of EIS on duplication of highways. It shall be highlighted, though, that the study only reflected the reality of a specific case in the area of São José do Rio Preto-SP, and, therefore, its considerations should not be generalized to other projects or areas. The analysis of a greater number of projects and highways would be more accurate to reflect the reality of the EIS in Brazil and/or in the state of São Paulo.

The limitation of this study comprises the lack of information about some items that were not found on the EIS. Besides, it is worthy highlighting that the analyzed EIS was the one primarily sent to IBAMA, having subsequent corrections or technical advices not been considered, that is, the 
study reflected the first analysis of the project. Finally, further and broader researches on the modifications done in the EIS after IBAMA's technical advices are recommended to observe whether gaps still occur after the alterations.

\section{REFERENCES}

AGÊNCIA NACIONAL DE TRANSPORTES TERRESTRES (ANTT). Superintendência de Exploração de Infra-Estrutura Rodoviária. Rodovias reguladas pela ANTT - Relatório anual 2008. Brasília-DF, 2008.

AGÊNCIA NACIONAL DE TRANSPORTES TERRESTRES (ANTT). Superintendência de Exploração de Infra-Estrutura Rodoviária. Rodovias reguladas pela ANTT - Relatório anual 2009. Brasília-DF, 2009.

AGÊNCIA NACIONAL DE TRANSPORTES TERRESTRES (ANTT). Superintendência de Exploração de Infra-Estrutura Rodoviária. Rodovias reguladas pela ANTT - Relatório anual 2010. Brasília-DF, 2010.

AGÊNCIA NACIONAL DE TRANSPORTES TERRESTRES (ANTT). Superintendência de Exploração de Infra-Estrutura Rodoviária. Rodovias reguladas pela ANTT - Relatório anual 2011. Brasília-DF, 2011.

AGÊNCIA NACIONAL DE TRANSPORTES TERRESTRES (ANTT). Superintendência de Exploração de Infra-Estrutura Rodoviária. Rodovias reguladas pela ANTT - Relatório anual 2012. Brasília-DF, 2012.

ALMEIDA, M. R. R. E.; MALFARA, D. T.; CRESPO, N.; MORAES, M. C. P.; SOUZA, M. P.; MONTAÑO, M. Aplicação de métodos para revisão da qualidade de estudos de impacto ambiental. Revista de Gestão Ambiental e Sustentabilidade, São Paulo-SP, v. 1, p. 1-29, 2012.

APPIAH-OPOKU, S. Environmental Impact Assessment in Developing Countries: The Case of Ghana. Environmental Impact Assessment Review, New York, v. 2, p.159-71, 2001.

BRASIL. Lei $n^{\circ}$ 6.938, de 31 de agosto de 1981. Dispõe sobre a Política Nacional do Meio Ambiente, seus fins e mecanismos de formulação e aplicação, e dá outras providências. Diário Oficial [da] República Federativa do Brasil, Brasília, DF, 31 ago. 1981. Disponível em: <http://www.planalto.gov.br/ccivil_03/leis/16938.htm>. Acesso em 15 jul. 2015.

CANELASA, L.; ALMANSAA, P.; MERCHANB, M.; CIFUENTES, P. Quality of environmental impact statements in Portugal and Spain. Environmental Impact Assessment Review, New York, v. 25, p. 217- 225, 2005.

CONSELHO NACIONAL DO MEIO AMBIENTE. Resolução n 001, de 23 de janeiro de 1986. Diário Oficial [da] República Federativa do Brasil, Brasília, DF, 17 fev. 1986. Disponível em: <http://www.mma.gov.br/port/CONAMA/res/res86/res0186.html>. Acesso 15 jul. 2015.

CONSELHO NACIONAL DO MEIO AMBIENTE. Resolução n 237, de 19 de dezembro de 1997. Diário Oficial [da] República Federativa do Brasil, Brasília, DF, 22 dez. 1997. Disponível em: <http://www.mma.gov.br/port/CONAMA/res/res97/res23797.html>. Acesso 15 jul. 2015. 
COOPER, D.; SCHINDLER, P. Business Research Methods. 12. ed. New York: McGrawHill/Irwin, 2014.

DNIT - DEPARTAMENTO NACIONAL DE INFRAESTRUTURA DE TRANSPORTE.

Nomenclatura das rodovias federais: rodovias longitudinais. 2015. Disponível em:

$<$ http://www.dnit.gov.br/rodovias/rodovias-federais/nomeclatura-das-rodovias-federais/rodoviaslongitudinais.pdf >. Acesso em 15 jul. 2015.

ENVIRONMENTAL RESOURCES MANAGEMENT. Guidance on EIA-EIS Review. Luxembourg: Office for Official Publications of the European Communities, 2001.

EUROPEAN UNION. Directive 85/337/EEC of 27 June 1985. On the Assessment of the Effects of Certain Public and Private Projects on the Environment. Official Journal, 05 jul. 1985. Disponível em: < http://eur-lex.europa.eu/legal content/EN/TXT/?uri=CELEX:31985L0337>. Acesso em 15 jul. 2015.

EUROPEAN UNION. Directive 97/11/EC of 3 mar. 1997. Amending Directive 85/337/EEC on the Assessment of the Effects of Certain Public and Private Projects on the Environment. Official Journal, 14 mar. 1997. Disponível em: <http://eur-lex.europa.eu/legalcontent/EN/TXT/?uri=CELEX:31997L0011>. Acesso em 15 jul. 2015.

FERNANDES, J. P. Landscape Ecology and Conservation Management - Evaluation of Alternatives in a Highway EIA Process. Environmental Impact Assessment Review, New York, v. 20, p. 665$680,2000$.

GALHARTE, C. A.; CRESTANA, S. Avaliação do impacto ambiental da integração lavourapecuária: aspecto conservação ambiental no cerrado. Revista Brasileira de Engenharia Agrícola e Ambiental (Online), v. 14, n.11, p. 1202-1209, 2010.

GLASSON, J.; THERIVEL, R.; CHADWICK, A (2005). Introduction to Environmental Impact Assessment. 3. ed. London: Routledge, 2005. p. 395-407.

INTERNATIONAL ASSOCIATION FOR IMAPCT ASSESSMENT. Principles of Environmental Impact Assessment Best Practice. Fargo, 1999. 1 v.

JAYA, S.; JONES, C.; SLINN, P.; WOOD, C. Environmental Impact Assessment: Retrospect and Prospect. Environmental Impact Assessment Review, New York, v. 27, p. 287-300, 2007.

KAJA, P. Quality of Environmental Impact Statements and Variability of Scrutiny by Reviewers. Environmental Impact Assessment Review, New York, v. 30, p. 169-176, 2010.

MACINTOSH, A. The Australian Government's Environmental Impact Assessment (EIA) Regime: Using Surveys to Identify Proponent Views on Cost-Effectiveness. Impact Assessment and Project Appraisal, v. 28, n. 3, p. 175-188, 2010.

MINISTÉRIO DO PLANEJAMENTO. BR153/SP - Travessia urbana de São José do Rio PretoSP. [S.1.: s. n.], 2014. Disponível em: <http://www.pac.gov.br/obra/55942>. Acesso em 15 jul. 2015. 
MONTAÑO, M.; CARVALHO, A. F.; GOMES, C. S.; POLAZ, C. N. M.; JORDÃO, C. O.; SOUZA, M. P. Revisão da qualidade de Estudos de Impacto Ambiental de Pequenas Centrais Hidrelétricas. HOLOS Environment (Online), v. 14, p. 1-14, 2014.

PREFEITURA MUNICIPAL DE SÃO JOSÉ DO RIO PRETO-SP. Estudo ambiental: duplicação rodoviária e travessias urbanas BR 153/SP do KM 54,3 ao KM 72,1. São José do Rio Preto, 2009. CD-ROM.

SADLER, B. (Org.). Environmental Assessment in a Changeling World: Evaluating Practice to Improve Performance. Ottawa: Canadian Environmental Assessment, 1996.

SÁNCHEZ, L. E. Avaliação de impacto ambiental: conceitos e métodos. São Paulo: Oficina de Textos, 2006.

TRANSBRASILIANA CONCESSIONÁRIA DE RODOVIA S.A. A rodovia. Disponível em: <http://www.triunfotransbrasiliana.com.br/Mapa.aspx>. Acesso em 15 jul. 2015.

UNITED STATES OF AMERICA. National Environmental Policy Act of 1969. Public Law 91190. As Amended Through Dec. 31, 2000. Washington, DC, 31 dez. 2000. Disponível em: <http://www.epw.senate.gov/nepa69.pdf>. Acesso em 15 jul. 2015.

WUA, C.; LINB, Y.; CHIANGC, L.; HUANGD, T. Assessing Highway’s Impacts on Landscape Patterns and Ecosystem Services: A Case Study in Puli Township, Taiwan. Landscape and Urban Planning, v. 128, p. 60-71, 2014. 